THE MUSEUM

OF THE

BROOKLYN INSTITUTE OF ARTS AND SCIENCES.

SCIENCE BULLETIN

Vol. I : No. 3 .

\title{
THE ATLANTIC PALOLO,
}

BY

ALFRED GOLDSBOROUGH MAYER.

WITH ONE PLATE.

Publahed by the Macmllan Company, 66 Fifth Avenue, New York.

DECEMBER， I 902. 
Digitized by the Internet Archive in 2016 


\title{
THE ATLANTIC PALOLO.
}

\author{
(EUNICE FUCATA.)
}

\section{By Alfred Goldsborough Mayer.}

The present paper has been revised by my friend Professor Thomas H. Montgomery, to whom I am indebted for valuable suggestions. I am also grateful to Captain A. B. H. Lillie, U. S. N., for his kindness in granting transportation upon the Naval Tug "Osceola" to and fro between Key West and the Dry Tortugas.

In Igoo I published a paper* upon an Annelid whose breeding habits are similar to those of the well known "Palolo" worm of Samoa and Fiji.

In this paper I made very serious errors which were fortunately pointed out by Ehlers, ${ }^{*} *$ Friedlaender, $\dagger$ and others. ${ }^{\ddagger}$ These errors are as follows: I thought that the entire worm swam at the surface at the time of the breeding-swarm, whereas in fact only the sexually mature posterior segments swim at the surface, while the whole anterior part of the worm remains below and takes no part in the swarm. The sexually mature posterior segments swim backivards, and what I described as the "head" of the worm is in reality the posterior segment.

Moreover, the worm is Eunice fucata, not a new species of Staurocephalus as I supposed.

During the summer of 1902 I went again to the Dry Tortugas, Florida, in charge of an expedition under the auspices of the Museum of the Brooklyn Institute of Arts and Sciences, and obtained hundreds of the worms in all stages of growth.

\footnotetext{
*An Atlantic "Palolo," Staurocephalus gregaricus, Bulletin of the Museum of Comparative Zoology at Harvard College, Vol. XXXVI, p. I-r 4, Plates I-III.

** E. Ehlers, 1901; Nachr. Ges. Wiss. Göttingen Math. Nat. C1., 4 Heft.

† Benedict Friedlaender, 190x; Biologischer Centralblatt, Bd. XXI, Nr-10, 11, p. 312-317 ; $352-366$.

$\ddagger$ A. E. Verrill, xgoo; Trans. Connecticut Acad., Vol. X, p. 65o, proposed the generic name "Mayeria" for the worm. This name cannot stand, for the worm is a Eunice.
} 


\section{Habits of the Atlantic Palolo.}

The Atlantic Palolo worm is Eunice fucata, described and figured by Ehlers, i887.* It is abundant at the Dry Tortugas, Florida, and is recorded by Treadwell from the reefs of Porto Rico, ${ }^{\dagger}$ and will probably be found to be widely distributed over the Bahama Reefs. It has not been recorded from the Bermudas. It lives within dead and disintegrating coral rock or corroded coquina, in long, tortuous, smoothwalled burrows of uniform bore; just wide enough to accommodate the worm itself. The animal commonly lies ${ }^{\circ}$ coiled upon itself within this burrow, and very often Polynoe granulata, Ehlers, is found sharing the same burrow with the Palolo. The worm does not live in new and compact coral rock, or in coquina of recent formation. It is, however, abundant in coral rock or coquina which is disintegrating, and has become infested with Pholas, other worms, Crustacea, etc. The burrow of the Palolo always opens outward at the surface of the rock although as far as I know the worm never leaves its burrow permanently until the time of the breeding-swarm. Thirteen rocks containing Palolo worms were kept in a canvas bucket below low tide level from June 24 to July 28, 1902, and during this interval they remained within their burrows. The worms feed chiefly upon Marine Algae.

The worm is common everywhere over the Tortugas reefs from immediately below low tide level to a depth of at least six fathoms. Large numbers of them are found in the dead coral to the westward of Loggerhead Key in N. Lat. $24^{\circ} 38^{\prime}$ I $5^{\prime \prime}$, Long. W. from Greenwich $82^{\circ} 56^{\prime} 30^{\prime \prime}$.

\section{The Breeding-Swarm.}

The Atlantic Palolo swarms within three days of the time of the moon's last quarter between June 29-July 28. The following table shows the dates of the swarms of the years I898-1900, 1902; the dates of the moon's last quarter, and the period during which the ocean was watched continuously, morning after morning.

\footnotetext{
* E. Ehlers, 1887 ; Reports on the results of Dredging, etc., in the Gulf of Mexico, and in the Caribbean Sea, Memoirs of the Museum of Comparative Zoology at Harvard College, Vol. XV, p. 91, Taf. 25, Fig. 8-20.

†A. L. Treadwell, rgor; U. S. Fish Commission Bulletin for rgoo, Part 2, p rg6.
} 


\begin{tabular}{|c|c|c|c|c|}
\hline Year. & $\begin{array}{l}\text { Date of the } \\
\text { Breeding- } \\
\text { Swarm. }\end{array}$ & $\begin{array}{c}\text { Date of } \\
\text { the } \\
\text { Moon's } \\
\text { last } \\
\text { Quarter. }\end{array}$ & $\begin{array}{l}\text { Period during which the Ocean } \\
\text { was observed continuously } \\
\text { every morning between } 4^{-6} \\
\text { A. M. }\end{array}$ & Observer. \\
\hline 1898 & July 9, & Iuly ro & 56 days, June $25-$ & A. G. Ma \\
\hline 1899 & $I$. & July 29 & 49 days, May I 7 -July 4. & A. G. Maye \\
\hline 1900 & July $19 \ldots$. & July i 8 & 6 days, June $19-20$, July I6-I 9 & Geo. R. Billberr \\
\hline 190 & & July 8 & 4 days, July 7 -10 ....... & Geo. R. Billberry. \\
\hline 1902 & July $24,25.28$ & July 27 & 4I days, June I9-July 29. & A. G. Mayer. \\
\hline
\end{tabular}

The dates of the principal swarms are printed in italics.

The above table shows that the ocean has been watched continuously for 146 days during the years 1898 , '99, 1902, and that no other swarms of the Palolo appeared excepting those upon or near the day of the last quarter of the June 29-July 28 moon. Very careful and prolonged search was made for the worm during the periods of the June and August last quarters, but without result other than that recorded in the above table.

In 1898 great numbers of the sexual segments were seen swimming at the surface before sunrise on the morning of July 9. On July Io, however, very few worms could be found, and after this none could he discovered.

In 1899 a remarkably dense swarm came on the morning of July I, and only a few worms could be found on the morning of July 2.

In I900 Mr. George R. Billberry, keeper of the lighthouse at the Dry Tortugas, kindly watched for the worms and having found them upon the morning of July 19, sent specimens to me preserved in alcohol.

In I90I, Mr. Billberry again watched for the worm from July 7-IO, the last quarter falling on July 8, but he failed to find the worms, and we know nothing of the swarm of I9OI.

In I902, no worms were to be found until July 24, when they appeared in considerable numbers. On the morning of July 25, however, they were much more numerous. None were found after careful search on the mornings of July 26 and 27 , but on the morning of July 28 , two swimming worms were seen, and several hundred freshly laid eggs were obtained in the tow net. No worms were to be found on the morning of July 29.

\section{Description of the Sicarm.}

The sexual clements are confined to the posterior segments of the worm. This sexual portion being on the average $145 \mathrm{~mm}$. long and composed of about I 55 segments. All but the hindermost 25-30 
segments contain sexual products. In the male these sexual segments are generally pink, while in the female they are dull sagegreen or brownish yellow. These colors are entirely due to the color of the contained sexual elements, however, for when the eggs or sperm are discharged the swimming segments of both sexes are dull brick-red in color.

When the swarm occurs the hinder end of the worm crawls out backwards from the burrow, and attempts to swim away from the anterior non-sexual part which remains within the burrow and takes no part in the swarm. A constriction appears allowing the sexual portion to break away from the anterior part of the worm; and immediately the posterior end swims with great rapidity almost vertically upward to the surface, upon reaching which it continues to swim hind end foremost parallel with and very near to the surface of the ocean. This occurs at least two hours before sunrise for I found the Palolo swimming at $3.20 \mathrm{~A}$. M. on July 25, 1902. The worms swim in all directions and begin to discharge sperm or ova through their nephropores, hut the least stimulus, such as being lifted from the water, or the current from the stroke of an oar, will cause them to contract violently, often breaking themselves into fragments and casting the sexual products out through rents in the cuticula. This normally occurs as soon as the first rays of the sun fall upon the water, and in a few minutes after sunrise all of the worms will have completely freed themselves of genital products, and the ocean becomes milky in appearance due to the vast quantity of sperm and ova floating within it. The worms continue to swim but they gradually sink down and disappear so that none are to be seen two or three hours after sunrise. In a dense swarm there may be on an average about one worm per square foot over wide areas of the sea. The worms are commonest in places where the water is about 6 fathoms in depth. Great numbers of the worms are devoured by fishes as they sink, although they are not attacked to any great extent while upon the surface. When set free the sexual ends swim vertically upwards with such rapidity that they run little risk of capture, and this habit must be a great advantage to the worm. If the swimming worm be broken into fragments each piece continues to swim backward in a normal manner, showing that the reaction is not controlled by any one ganglion or localized group of ganglia, but that the whole sexual end of the worm is affected by the stimulus which causes the breeding-swarm. 
The females are much more sensitive than the males. Males may readily be killed in weak alcohol or formalin without casting out their sexual products, whereas it is difficult to preserve perfect females in this manner. A count of I80 worms collected at random gave Io 3 males and 77 females. It appears, therefore, that there are about $57 \%$ of males and $43 \%$ of females.

\section{Growth and Devclopment.}

The eggs float at or near the surface, and are in the 4-16 cell stages at about 7 A. M. The segmentation is total and unequal, and the gastrula is formed by epibole. The larva is telotrochal, and possesses two eyes and large ectodermal cephalic glands. It swims through the water until four pairs of setigerous appendages have developed, after which it sinks to the bottom. The development was described in detail by the author in 1900 .

During June and July, 1902, large numbers of coral rocks were broken open and many hundreds of the complete worms were obtained. The worms appeared to be of two sizes, small slender ones about 90-200 $\mathrm{mm}$. long, and large stout ones $250-350 \mathrm{~mm}$. in length.

The great majority were slender and about $200 \mathrm{~mm}$. in length and showed no signs of being sexually mature, while the large worms were all developing sexual products in their posterior segments. Only about one worm in a dozen was developing sexual products, and on July 28 after the last swarm I broke open a large number of rocks and obtained 43 worms. Three of these were of large size and their posterior ends were constricted, the sexual segments having evidently been recently cast off. The constricted ends had healed but no regeneration had taken place. (See figure 7.) The remaining 40 worms were $140-225 \mathrm{~mm}$. in length and 36 of them were complete, two were regenerating at the posterior end of the body, and two had recently lost the extreme posterior segments apparently through accident in being cracked out of the rock, for the ends had not yet healed. All of these 40 worms were shorter and more slender than those which had evidently possessed sexual segments, and none of them were sexually mature. It appears, therefore, that the worm requires at least two years to attain sexual maturity, and that only about one worm in a dozen gives rise to sexual segments in any one year. This may represent the ratio of survival of the worms, only about one in twelve living to be two or more years old. 
It seems reasonable to suppose that the anterior part of the worm regenerates a new posterior end after the swarm. Many regenerating worms of all sizes are found, and, indeed, I had two worms whose posterior ends were broken off on June 25 , and maintained them alive within coral rocks kept beneath low tide level until July 28 , and during this period they had regenerated slender, tapering posterior ends about $4.5 \mathrm{~mm}$. long (see Figure 6).

\section{Experiments on Fertilization, Etc.}

When rocks containing the Atlantic Palolo are cracked open the worm begins to crawl out backward, but when about half of the length of the worm has emerged, the anterior part attempts to return into the burrow while the posterior part struggles to swim backward. A constriction appears between the two ends, and the posterior part of the worm is set free and swims through the water, while the anterior crawls back into the rock. In large worms 'with well developed sexual segments the break is apt to appear exactly at the junction between the sexual segments and the non-sexual anterior part of the worm. The sexual segments then swim rapidly backward and upward to the surface, where they continue to swim backward with great activity. Soon, however, they begin to contract violently, casting sperm or ova out into the water very much as in a normal swarm. It appears that the shock given to the worm upon cracking the rock acts as an abnormal stimulus to produce the drama of the breeding-swarm, which can be produced in this manner at any time of the day. On July I2, I7, I9 and 23, I902, I obtained eggs and sperm from worms which had thus been induced to go through with the actions of a swarm, but although the sperm was very active, and appeared to be normally attracted by the eggs, not one living embryo was obtained, although many of the eggs seymented abnormally. It was remarkable that eggs obtained at 4 P.M. on July 23 could not be fertilized although less than I 2 hours afterwards the normal swarm occurred in which practically every egg was fertilized. This is due to the fact that none of the eggs become mature until the time of the normal swarm when all of the eggs mature simultaneously. Full-grown female worms which had discharged some eggs were killed on July i2 and 23, at 4.30 P.M., in a saturated solution of corrosive sublimate in $35 \%$ alcohol; and four females which were swimming in the swarm at 4.20 A.M. on July 24 were similarly treated. Figure A shows the condition of the eggs 
in the females killed on July I 2 and 23. The nucleus is central in position, the nuclear membrane is complete, and there is a large nucleolus. Figure B, on the other hand, shows the condition of the eggs within the females killed during the swarm at 4.20 A.M. on July 24. 'The eggs are now about to give off the first polar globule. The nucleus has migrated to the surface at the animal pole, the nuclear membrane has disappeared, the nucleolus has broken up into small spherical fragments, ${ }^{*}$ and the first polar globule is not yet constricted off from the egg.

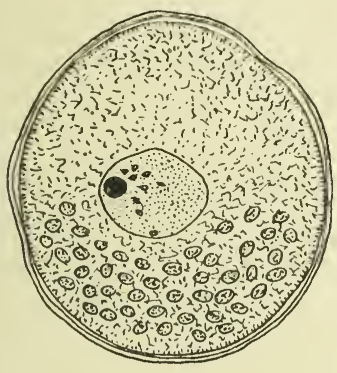

FIG.A

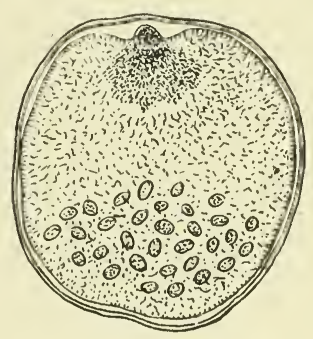

FIG.B

I hoped to discover whether the Atlantic Palolo responds in its swarm to the light, or to some attraction due solely to the position of the moon. Accordingly a number of worms were maintained alive within coral rocks beneath low tide level, and on the nights of July 23-28, 1902, the rocks containing the worms were placed in glass aquaria which were shut up within a wooden boat shed into which no direct moonlight could penetrate. None of these worms swarmed, but upon cracking open the rocks I discovered that all of the worms were immature. The experiment is therefore inconclusive and should be repeated.

In Igoo I advanced the view that the Palolo may be regarded as an animal in which the egg-laying season has been reduced to a period of one or two days; and that it could be shown mathematically that a shortening of the egg-laving period causes a greater concentration of breeding individuals and therefore shortens the average distance that the spermatozoa must travel in orcler to fertilize the

\footnotetext{
*Not shown in this individual section.
} 
ova. This advantage would allow of an increase in the relative number of females and a reduction in the number of males, and thus more eggs would be produced. The short breeding season of the Palolo may, therefore, have been brought about through the agency of natural selection, provided the ancestors of the Palolos now living possessed an initial tendency to swarm at or near the period of the moon's last quarter rather than at other times, and that this tendency was of a sort that would be perpetuated by inheritance.

Friedlaender, I90I, combats this view, holding that the Darwinian explanation is inadequate. He maintains that the Palolo responds to a certain condition of the tide in conjunction with an influence which the moon exerts upon the worm when at the position of last quarter, and that the response of the worm has not been brought about through natural selection.

It is interesting to observe, however, that the condition of the tide at the Tortugas, Florida, upon the day of the last quarter of the July moon is quite different from its condition at Samoa and Fiji upon the days of the last quarter of the October and November moons. At these times in Fiji and Samoa the tide is about at its lowest when the sun rises, while at the Dry Tortugas the tide is ebbing but is still about $\mathrm{I} / 4-23 / 4$ hours high. For example: On July 27, I902, at the Dry Tortugas low tide occurred I hour and $22 \mathrm{~min}$ utes after sunrise, while at Apia, Samoa, on October 23 and November 2I, I9O2, low tide came at I and at I4 minutes after sunrise on the respective dates. Also the mean rise and fall of the tide at the Dry Tortugas is only I.I feet, while at Samoa and Fiji it is 2.2-3.7 feet. All that we can say is that Atlantic and Pacific Palolos swarm upon or near the day of the last quarter of the moon, at corresponding seasons of the year, for the meteorological conditions and temperature of the water at the Tortugas in July are remarkably similar to those at Samoa and Fiji in October and November. The worm no doubt responds to some physical stimulus which is dependent upon the condition or position of the moon, but the exact nature of this stimulus remains to be discovered.

\section{Description of the Mature Worm.}

A minute description of Eunice fucata is unnecessary, as the worm has been well described by Ehlers, I887; Mem. Mins. Comp. Zool. at Harvard Coll., Vol. XV, p. 91, Pl. 25. Ehlers, however, had 
access only to alcoholic specimens, and a few details may be added from an inspection of living worms. The entire worm is shown in Fig. I, the figure being of natural size and drawn from a living male worm on Juné 23, I902. The posterior sexual segments are not yet fully developed and are destined to become about twice as long and about one-half again as wide as in the figure. Figure 2 gives a dorsal, and Figures 3 and 4 ventral and lateral views of the head, magnified four times. The præstomium exhibits a longitudinal dorsoventral cleft dividing it into two lateral lips, each of which bears a pad-like thickening on its ventral surface. The dorsal sides of the first segment bear five antennæ, one median and four lateral. The eyes are large and are situated between the two lateral pairs of antennæ. The segment back of the head bears no appendages, while the following segment bears only a pair of dorsal cirri. In full-grown worms the four succeeding segments are provided with lateral parapodia which lack gills. In younger worms there may be five or six of these appendages without gills. The gills are, however, found upon all of the following parapodia of the body excepting those of the sexual segments. The gills of the anterior third of the body are the best developed, and are provided with 7-IO simple lateral filamențs. These filaments become reduced in number back of the first third of the worm's length and in the middle of the body the gills have no lateral filaments and are reduced to mere stumps. They disappear entirely at the point of junction of the body segments with the posterior sexual part of the worm, so that the sexual segments are not provided with gills. The external surface of the gills is covered with active cilia. The hindermost segment of the body bears a pair of ventral cirri. It is interesting to observe that the young larva bears a pair of dorsal as well as a pair of ventral cirri upon its posterior segment. As the adult worms never possess these dorsal cirri they must degenerate, leaving only the ventral pair. The anterior third of the worm is of a rich bronze-brown with iridescent color playing over it. The mid-region of the body is duller in color being brown or brown-red. The sexual segments are pink or dull salmon-yellow in the male while in the female they are dull sage-green or dull brownish-yellow. These color differences are, however, due entirely to the color of the contained sexual elements, for when these are discharged the sexual segments of both sexes become dull brick-red in color. The gills are of a rich purple-red color, while the parapodia are light greenish-yellow. The 
worm is very active in captivity and when disturbed will often protrude its jaws and snap viciously. Full-grown worms are about $350 \mathrm{~mm}$. long. The anterior non-sexual part consists of about 225 segments and the posterior sexual part of about I 50 segments.

\section{Summary:}

The "Atlantic Palolo" is Eunice fucata, Ehlers. It is found at the Dry Tortugas, Florida, and lives within disintegrating coral rock or coquina from below low tide level to a depth of at least six fathoms. Its breeding habits are closely similar to those of the well-known Pacific Palolo worm (Eunice viridis).

The Atlantic Palolo swarms at the surface before sunrise within three days of the day of the last quarter of the moon between June 29-July 28 . The posterior, sexually mature end of the worm breaks away from the anterior end, and swims backwards and upwards to the surface where it continues to swim backward with great rapidity until about the time of sunrise, when it contracts, casting the genital products out into the water. The anterior part of the worm remains below in the coral rock. The worm requires at least two years to attain sexual maturity. There are $57 \%$ of males and $43 \%$ of females. Only sexually mature worms cast off their posterior ends at the time of the swarm. The immature worms are about twelve times as numerous as the mature.

The shock produced by cracking the coral rock acts as a stimulus to produce the drama of the breeding-swarm before the normal date of the swarm. Eggs obtained in this manner are immature and cannot be fertilized, even twelve hours before the time of the normal swarm. All of the eggs mature simultaneously at the time of the normal swarm.

The normally laid eggs float in the water and begin to segment soon after extrusion from the worm. The segmentation is total and unequal, the gastrula is formed by epibole, and the larva is telotrochal. The young larvæ swim near the surface, but sink to the bottom upon attaining four pairs of setigerous lobes. The posterior segment of the larva bears a pair of clorsal as well as a pair of ventral cirri. Only the ventral pair of cirri persist in the fully developed worm.

Museum of the Brooklyy Institete of Arts . ind Sciences. August, 1902. 


\section{LIBRARY}

OF THE

UNIVERSITY OFILLINOI: 


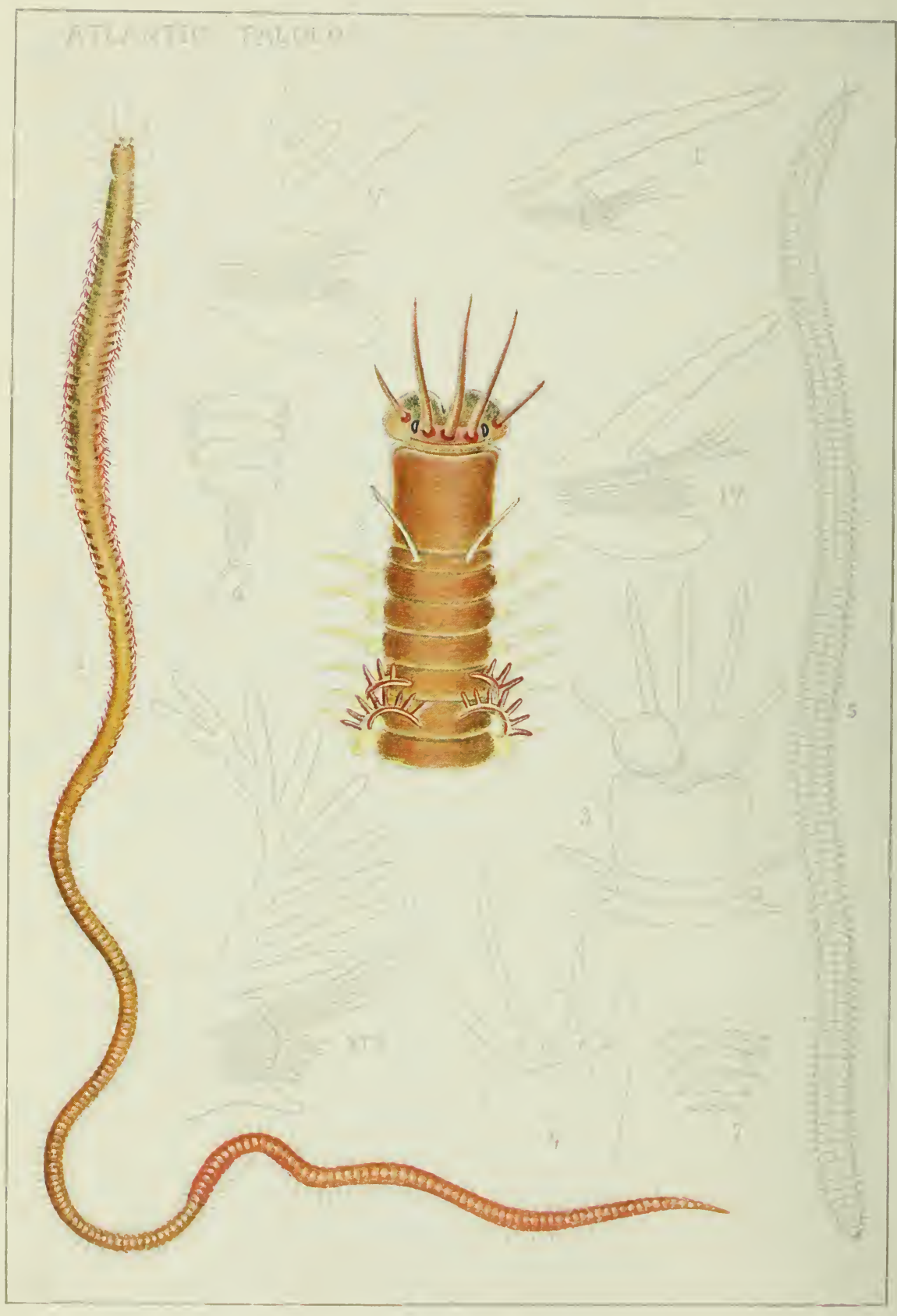


Explanation of the Plate.

Figure I: Male Specimen of the Atlantic Palolo Eunice fucata, natural size. Drawn from life on June 23, I902, one month before the date of the breeding-swarm. The sexual segments are not yet fully developed, and finally become about twice as long and onehalf again as wide as in this figure. (See Figure 5.)

Figure 2: Dorsal view of the head, magnified four times. Drawn from life.

Figure 3: Ventral view of the head showing the lip-like pads of the præstomium. Magnified four times.

Figure 4: Side view of the head. Magnified four times.

Figure 5: Sexually mature swimming-segments. Natural size. Drawn from a specimen found upon the surface of the sea at 4.20 A.M., on July 25, I902. The hind end is represented above and the constricted anterior end below. The hind end is always directed forwards in swimming.

Figure 6: Showing the amount of regeneration which took place at the broken posterior end of a worm between June 25-July 28 . The figure is three times natural size.

Figure $7:$ The constricted posterior end of the non-sexual anterior part of the Palolo. Found on July 28, two or three days after the posterior sexual-segments had been constricted off. No regeneration is as yet apparent although the last remaining segment has contracted and the wound has completely healed. This figure shows the swollen transverse ridges which are peculiar to the mid-dorsal tract of the worm. The figure is two and one-half times natural size.

Figures I, IV, V, and XIX: The first, fourth, fifth and nineteenth parapodia respectively. The first four pairs of parapodia lack gills. The fifth possesses a small gill with two lateral filaments. These lateral filaments increase in number and there are 7 -IO of them upon the parapodia of the anterior third of the worm's length, as is shown in the figure of the nineteenth parapodium. 

AGRICULTURE (See also Botany, etc.), THE RURAL SCIENCE SERIES

Edited by PROF. L. H. BAILEY, Cornell University. Prices from 75 cts. to $\$ 1.50$

Including Prof. Bailey's Principles of Agriculture, Cards' Bush Fruits, Jordan's Feeding of Animals, King's The Soil-Irrigation and Drainage, Robert's Fertility of the Land, Voorhees' Fertilizers, Watson's Farm Poultry, Wing's Milk and its Products.

ANATOMY, PHYSIOLOGY, Etc.,

CUNNINGHAM'S Text Book of Anatomy.

Edited by D. J. CUNNINGHAM, F.R.S., M.D., D.Sc., LL.D., D.C.L., and Professor of Anatomy and Chirurgery, Trinity College, Dublin. With more than 800 illustrations, many of which are in color.

Cloth, 8vo., \$9.00; sheep, \$10.00: hf. mor., \$1 I.00. For other works on these subjects by Agassiz and Gould, Cleland and Mackay, Foster, Halleck, Huxlev, McKendrick, Mivart, Schaffer, Verworn, Warner, Wiedersheim, etc., see their General Catalogue.

ANTHROPOLOGY, Etc.

WESTERMARCK. The History of Human Marriage.

By EDWARD WESTERMARCK, Lecture on Sociology at the University of Finland, Helsingfors. [Third Edition.] $20+644$ p. $8^{\circ} \cdot \mathrm{cl}$., net. $\$ 4.50$.

For other books such as Chamberlain's Child and Childhood in Folk-thought, Crawley's 'The Mystic Rose, Fielding's The Soul of a People, Frazer's the Golden Bough, Hoffman's American Negro, Skeats' Malay Magic, Wallace's Works, Yoe's The Burman, etc.; see their General Catalogue.

ASTRONOMY.

\section{MOULTON'S Introduction to Celestial Mechanics.}

By FOREST RAY MOULTON, Ph. D.. Instructor in Astronomy, Chicago University. Cloth, 8 vo., Illustrated, $\$ 3.50$ net (postage 18 ets.)

For other books such as Ball's Astronomy, Blake's Astronomical Myths, Brown's Lunar Theory, Clerke's Astronomy, Lockyer's works, etc., see their General Catalogue.

BIOLOGY, ZOOLOGY, Etc.

\section{BOURNE'S An Introduction to the Study of Compara-} tive Anatomy of Animals.

By GILBERT C. BOURNE, M.A., D.Sc., F.L.S, Fellow and Tutor of New College, Oxford, University Lecturer in Comparative Anatomy.

\section{Vol. II. The Colomate Metazoa.}

I $5+32$ I p il. $\mathrm{r}^{\circ}, \mathrm{cl}$, net, $\$ 1.25$.

For books on these and connected topics by Campbell, Davenport, Foster and Balfour, Hertwig, Korschelt and Heider, Lang, Morgan, Osborn, Packard, Parker, Shipley, etc., etc., including the contributors to the Cambridge Natural History, see their General Catalogue.

Continued on the next page. 


\section{Selected List (Continued) of the Publications of The Macmillan Company}

BOTANY.

\section{CAMPBELL'S University Text $=$ Book of Botany .}

By DOUGLAS HOUGHTON CAMPBELL, Ph.D., Professor of Botany in the Leland Stanford Junior University. With many illustrations.

Cloth, 8 vo, 579 pp., \$4.00 Net (postage $24 \mathrm{cts}$.)

For other works such as Bailey's Botany, Ganong's The Teaching Botanist Scott's Structural Botany, Setchell's Laboratory Practice, and the textbooks by Strasburger, Vines, Warmıng, etc., see their General Catalogue.

CHEMISTRY.

\section{JONES' Elements of Physical Chemistry.}

By HARRY C. JONES, Associate Professor of Physical Chemistry in the Johns Hopkins University. Cloth, $565 \mathrm{pp} ., 8 \mathrm{vo}, \$ 4.00$ Net (postage $23 \mathrm{cts}$.). For many other text-books by Gatterman, Hempel, Leng feld, Lewkowitsch, Menschutkın, Ostwald, Ramsay, Roscoe, Schorlemmer, Scott, Talbot, Thorp Thorpe, etc., see their General Catalogue.

GEOGRAPHY, GEOLOGY, Etc.

TARR'S Physical Geography of New York State.

By RALPH S. TARR, F.G.S.A., Professor of Dynamic Geology and Physical Geography at Cornell University. Cloth, 397 pp., 8 vo, \$3.50 Net (postage 23c). For other works by the same author and for Dr. Geikie's works, Hatch's Petrology, Merrill's Rocks, Russell's Volcanoes, Scott's Geology, and the Tarr and McMurry's Series of School Geographies, etc., see their General Catalogue.

HYGIENE, Etc.

SEDGWICK'S Principles of Sanitary Science and the Public Health.

By WILLIAM T. SEDGWICK, Ph.D., Professor of Biology and Lecturer on Sanitary Science and the Public Health, Mass. Inst. of 'Tech.

Cloth, 8vo, 368 pp., $\$ 3.00$ Net (postage $18 \mathrm{cts}$ ) Other works like Baker's Municipal Engineering. Beardmore's Drainage, Shaw's School Hygiene, etc., are to be found in their General Catalogue.

PHYSICS.

NICHOL'S and FRANKLIN'S The Elements of Physics.

A College Text-Book by EDWARI) L. NICHOLS and WILLIAM S. FRANKLIN. In Three Volumes. I. Mechanics and Heat, \$r.5o Net. II. Electricity and Magnetism, \$r.90 Net. III. Sound and Light, \$1.50 Net. A long list of text-books and works of reference on the different subjects included under the term Physical Science are to be found in the Genera Catalogue.

The General Catalngue referred to, as well as the occasional Announcement Lists, and the Monthly Lists of new books will be sent to any address, without charge, on application.

Books published at NET prices are sold by booksellers everywhere at the advertised NET prices. When delivered from the publishers, carriage, either postage or expressage, is an extra charge.

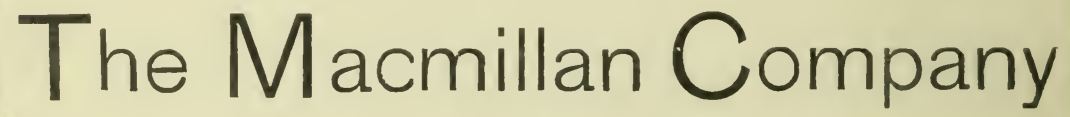
66 FIFTH AVENUE, NEW YORK. 


\section{PUBLICATIONS OF THE MUSEUM}

\section{OF THE \\ BROOKLYN INSTITUTE OF ARTS AND SCIENCES.}

These publications will be issued at irregular intervals, and will present the original researches of the Curators and Assistants of the Museum, and work by specialists based upon the Museum Collections. The announcements of the Science Bulletin will be found on the fourth page of the cover.

\section{MEMOIRS OF ART AND ARCHAEOLOGY.}

Each Memoir will be a complete publication and is for sale individually. Price of Vol. I., No. I; "A Renaissance Leaning Façade at Genoa," by Wm. H. Goodyear ; 50 cents. Price of Vol. I., No. 2; "The Architectural Refinements of St. Mark's at Venice." by Wm. H. Goodyear; \$1.50. In preparation, Vol. I., No. 3 .

\section{The Architectural Refinements of the Pisa Cathedral.}

This Memoir will contain not less than four double-page and eleven full-page plates of survey and not less than sixty pages of text and illustration.

Orders for purchase may be addressed to the Macmillan Company, 66 Fifth Avenue, New York. Exchanges and correspondence regarding exchanges may be addressed to the Librarian, Museum, Eastern Parkway, Brooklyn.

\section{Photographic Bromide Enlargements.}

Bromide enlargements of the photographs which are reproduced in these Memoirs are for sale by the Museum; sizes of $18 \times 22$ inches and of $25 \times 35$ inches. Price $\$ 5.00$ and $\$ 10.00$, respectively, mounted on white card.

These photographs may also be obtained by exchanges of $\mathrm{Mu}$ seum exhibits, in archæology, anthropology, or Natural History. They will also be exchanged for Library material. Orders or enquiries may be addressed to the Director. 


\title{
PUBLICATIONS OF THE MUSEUM
}

\author{
OF THE \\ BROOKLYN INSTITUTE OF ARTS AND SCIENCES.
}

These publications will be issued at irregular intervals, and will present the original researches of the Curators and Assistants of the Museum, work by specialists based upon the Museum Collections and Contributions from the Marine Biological Laboratory, at Cold Spring Harbor, Long Island, under the direction of Charles B. Davenport. For the publications of the Department of Fine Arts, see inner page of the cover.

\section{SCIENCE BULLETIN,}

Vol. I., No, I, upon The Variations of a newly arisen species of Medusa, and Vol I., No. 2 upon Effects of Natural Selection and Race-Tendency upon the color patterns of Lepidoptera, have been issued. Prices, 25 and 75 cents respectively.

The following are in course of preparation: The Birds of Long Island, by George $\mathrm{K}$. Cherrie. New species of Coleoptera from the United States, by Carl Schaeffer, The Instincts of Lepidoptera, by Alfred G. Mayer and Caroline G. Soule. The Marine Fauna of the Dry Tortugas, Florida, by Alfred G. Mayer with drawings by Herbert B. Judy.

One volume of the Science Bulletin will contain about 400 pages of printed matter or about 325 pages accompanied by 50 plates. Each number of the Science Bulletin is sold separately. A price list will be sent on application to the Macmillan Company, 66 Fifth Avenue, New York. The subscription price is $\$ 3.00$ per volume, payable in advance. Subscriptions should be sent in care of the Librarian of the Museum of the Brooklyn Institute of Arts and Sciences, Eastern Parkway, Brooklyn, New York. 